\title{
Ovarian Steroid Cell Tumor, Not Otherwise Specified
}

National Cancer Institute

\section{Source}

National Cancer Institute. Ovarian Steroid Cell Tumor, Not Otherwise Specified. NCI

Thesaurus. Code C39979.

A steroid cell tumor that arises from the ovary and is defined by morphologic features that do not fit into the categories of Leydig cell tumor and stromal luteoma. These features include solid proliferations of polygonal neoplastic cells with eosinophilic and granular cytoplasm. Grossly, these tumors usually present as large and well circumscribed masses and are usually associated with androgenic manifestations. Approximately one third of the cases have a malignant clinical course. 